\title{
Between Venice, Lubowla in Spiš and Kraków: Prince Teodor Lubomirski - An Enthusiast of Italian Opera (A Preliminary Study)
}

\author{
Anna Ryszka-Komarnicka / a.ryszka-komarnicka@uw.edu.pl \\ Institute of Musicology, Warsaw University, PL
}

\begin{abstract}
Prince Teodor Lubomirski staged 4 operas in his Polish estates: Venceslao, La fede ne'tradimenti, Mariane, Griselda (1725-1727). The Kraków prints of the libretti for the first 3 operas follow the Venetians prints $(1722,1721,1724)$, while the Cracovian Griselda is a pasticcio probably prepared on the base of the variant of the opera staged in Venice in 1720 (mus. G. M. Orlandini). Acting as a patron of opera in Poland was a part of a Teodor's well-thought-out policy aimed at standing out against the other Polish aristocrats, at bringing entertainments to himself and his morganatic wife and at an attempt to break the society's aversion by means of offering the attractions that were hardly accessible in Poland at the time. The repertoire of his theatre was in perfect accord with such aims, especially taking into consideration Zeno's Griselda, allegorically enhancing the status of Teodor's own wife and children. Teodor's ephemeral musical hobby was by no means uncommon in 18th-century Poland. Like many other Polish aristocrats he saw opera as a good way to improve his own social status, but contrary to the West-European royal and princely courts, he did not perceive the genre as the medium of political propaganda that would be worth money. So at the end of the twenties, when Teodor returned to political life, he gave up his operatic interests.
\end{abstract}

\section{Keywords}

Venetian opera, court opera, Apostolo Zeno, Venceslao, Griselda, La Mariane, La fede ne'tradimenti, Teodor Lubomirski, Kraków 
Prince Teodor Konstantyn Lubomirski (1683-1745) was one of the most influential aristocrats of Polish-Lithuanian Commonwealth during the first half of 18th century. As his mighty ancestors, he held numerous and lucrative offices, amongst others Starosta of Spisz [Spiš] and Voivode of Kraków Voivodeship. He held the hereditary, prestigious title of Prince of Holy Roman Empire. ${ }^{1}$ To this day there is no comprehensive, detailed study of Teodor's biography. The entry in the Polski Stownik Biograficzny [Polish Biographical Dictionary] remains the main source of information about him. However, it is focused on his controversial political activities. ${ }^{2}$ The main obstacle that makes such biographical studies difficult is the fact that Lubomirscy family ${ }^{3}$ archives are not merged. The studies upon biographies of other members of the family - e.g. Teodor's father, Stanisław Herakliusz - shown that the sources are broadly dispersed (including the correspondence). ${ }^{4}$ It may suggest, then, that there are possibly many more sources concerning Teodor's biography and his court affairs than those few listed in the abovementioned dictionary entry. Thus, my study that deals with operatic interests of Teodor Lubomirski is at present of contributory nature.

Teodor was not the first Lubomirski who had shown the interest in patronage upon arts and music. The great-grandfather of Teodor, Stanisław (1583-1649), kept at his court an ensemble of highly-qualified instrumentalists and singers, mostly of Italian origin. However, nothing is known for certain about the repertory performed by them. ${ }^{5}$ Alas, Stanisław's son (and Teodor's grandfather), Jerzy Sebastian (1616-1667), in the turbulent times of war had to put aside his interest in muses to devote himself to the military career. ${ }^{6}$ Son of Jerzy Sebastian, and Teodor's father, already mentioned Stanisław

1 The first Starost of Spisz was Teodor's great great-grandfather Sebastian Lubomirski (d. 1613), who received from the Emperor Rudolf II the title of Count of Holy Roman Empire of the German Nation. The title of Prince of Holy Roman Empire was confered to Teodor's great-grandfather Stanisław Lubomirski by the Emperor Ferdynand III. ZIELIŃSKA, Teresa. Poczet polskich rodów arystokratycznych [Polish Aristocratic Families]. Warszawa: Wydawnictwa Szkolne i Pedagogiczne, 1997, p. 134-135.

2 SZCZYGIELSKI, Wacław. [entry] Lubomirski Teodor h. Szreniawa. In Polski Stownik Biograficzny [Polish Biographical Dictionary]. Emanuel Rostworowski (ed.). Wrocław - Warszawa - Kraków: Zakład Narodowy im. Ossolińskich - Wydawnictwo Polskiej Akademii Nauk, 1973, vol. 18, p. 60-63.

3 According to Polish custom, talking about the family requires the use of plural form of the name, thus Lubomirscy as a plural form of Lubomirski. (Note of the translator).

4 KUNICKI-GOLDFINGER, Marek. Listy Stanisława Herakliusza Lubomirskiego [Letters of Stanisław Herakliusz Lubomirski]. In Stanistaw Herakliusz Lubomirski - twórca i dzieta [Stanisław Herakliusz Lubomirski - Author and Oeuvres]. Adam Karpiński - Estera Lasocka (eds.). Warsaw: Instytut Badań Literackich, 2004, p. 33-57.

5 CHANIECKI, Zbigniew. W sprawie kapeli Stanisława Lubomirskiego i początków opery włoskiej w Polsce [Remarks Upon Stanisław Lubomirki's Chapel and the Origins of Italian Opera in Poland]. Muzyka, 1968, vol. 13 , no. 3, p. 58-65.

6 During the Potop Jerzy Sebastian remained one of the few aristocrates who did not go over to the Swedish side. He organised the resistance that begun the all-Poland guerilla war against the invaders. Spisz [Spiš], administered by him, played a key-role. It was in the L'ubovňa Castle where the king of Poland, Jan Kazimierz [John Casimir] visited Jerzy Sebastian, making his position among Polish nobles even stronger. KERSTEN, Adam. [entry] Lubomirski Jerzy Sebastian h. Szreniawa. In Polski Stownik Biograficzny [Polish Biographical Dictionary]. Emanuel Rostworowski (ed.). Wrocław - Warszawa - Kraków: Zakład Narodowy im. Ossolińskich - Wydawnictwo Polskiej Akademii Nauk, 1973, vol. 18, p. 17. 
Herakliusz (1642-1702), a gifted man of letters himself, conducted activities as a patron of arts and the author of works written both in Polish and Latin.

The members of the family often travelled abroad. Almost every one of them undertook in his youth the grand tour of Europe, that typically took around two years, not counting the periods of study at the illustrious institutions in Germany and Italy (Jesuit or Piarist colleges, University of Padua, etc.). The research into the repertoire of Venice operas of 17 th - 18th c. brought some new information about the presence of Lubomirscy in the Most Serene Republic of Venice. During his study period in Padua, Prince Józef Karol Lubomirski (ca. 1660-1702) had visited Venice as well between November 1681 till mid-April 1682. ${ }^{7}$ On 11 November 1681, in company of six attendants, he went to the private theatre of Contarini family in Piazzola sul Brenta to watch the performance of an opera Ermelinda (libretto by Francesco Maria Piccioli, music by Domenico Freschi) along with the cream of Venice aristocracy. Following month, on 8 December, he graced with his presence the first performance of a dramma per musica dedicated to him Bassiano, ovvero Il maggior impossibile possibile at Teatro SS. Giovanni e Paolo (libretto by Matteo Noris, music by Carlo Pallavicino), ${ }^{8}$ and during carnival, on 20 January 1682, he attended the performance of Carlo, re d'Italia (again by Noris and Pallavicino). ${ }^{9}$ Alas, it is not known if that Venetian experience influenced in any way the musical life of Józef Karol's court in Poland. Again, the researchers usually focused on his public activities and military actions and in the area of art patronage the main area of interest so far was his architectural investments in various residences, including those made in cooperation with brilliant Tylman van Gameren. ${ }^{10}$ The records mention some member of Lubomirscy family who in January 1700 paid Venetian patrician Pietro Dolfin a visit in his home in San Cassiano district. According to E. Selfridge-Field it was Józef Karol's brother, however Józef Karol had no male siblings. ${ }^{11}$ The available sources allow to draw a hypothesis that it could be Teodor's paternal uncle Hieronim Augustyn (ca. 1647-1706), who at that time was travelling to Rome and Venice was possibly a stop on his route. ${ }^{12}$ It is also possible that it was Teodor himself, as he was abroad between 1700 and 1702, however we have no precise information where he actually was travelling to. Polish Biographical Dictionary gives the information (truly, of gutter press quality) that Teodor escaped with his father's maitresse, on the other hand it is known fact that his father had planned Teodor's and his brother Franciszek's grand tour to be taken

7 SELFRIDGE-FIELD, Eleanor. A New Chronology of Venetian Opera and Related Genres, 1660-1760. Stanford: Stanford University Press, 2007, p. 150-151.

8 Ibid., p. 150.

9 Ibid., p. 153.

10 PRZYBOŚ, Adam. [entry] Lubomirski Józef Karol h. Szreniawa. In Polski Stownik Biograficzny [Polish Biographical Dictionary]. Emanuel Rostworowski (ed.). Wrocław - Warszawa - Kraków: Zakład Narodowy im. Ossolińskich - Wydawnictwo Polskiej Akademii Nauk, 1973, vol. 18, p. 27.

11 SELFRIDGE-FIELD, op. cit., p. 153.

12 WIMMER, Jan. [entry] Lubomirski Hieronim Augustyn h. Szreniawa. In Polski Stownik Biograficzny [Polish Biographical Dictionary]. Emanuel Rostworowski (ed.). Wrocław: Zakład Narodowy im. Ossolińskich - Wydawnictwo Polskiej Akademii Nauk, 1973, vol. 18, p. 13. 
during this period. On 28 November 1699 Stanisław Herakliusz completed the manuscript containing the instructions for his sons concerning their travel. First, they had to go to Vienna to pay respects to the House of Habsburgs, with whom Lubomirscy had strong bonds, then the brothers were to head for France and to visit the Netherlands during their return journey. The Prince recommended an Italian trip as a separate undertaking. ${ }^{13}$ The plans were, possibly, subject to change and if the information of Teodor's affair is true, it would be quite logical that the couple fled to Venice where they could enjoy, undisturbed, the entertainments of the carnival.

The first reliable information about Teodor's stay in Venice, unknown so far to Polish researchers, dates from January 1712, when he became a dedicatee of the printed edition of the new opera La Merope by Apostolo Zeno and Francesco Gasparini. From the content of the ornate dedication, we can conclude that it was the librettist who penned it, despite the fact that he used N.N. as a signature (the author revealed himself in phrases such as "questo mio Dramatico componimento" ['this dramatic work of mine']). ${ }^{14}$ He praised Teodor's virtues that were, as author underlined, widely publicised abroad. This statement was probably an allusion to favours that were showered on Lubomirski by Joseph I (already late at the time). Teodor was leading anti-royal military campaigns during the first decade of Great Northern War (that took place in the years 1700-1721), and it was thanks to Emperor's mediation that Teodor was pardoned, his treason forgiven and his Starostship of Spisz reinstated. ${ }^{15}$

The Prince's subsequent stays in Venice, again unknown to Polish researchers, took place in 1722 and 1724. In the carnival of 1722 Apostolo Zeno's ${ }^{16}$ opera Venceslao was

13 LUBOMIRSKI, Stanisław Herakliusz. Instrukcyja synom moim [do] cudzych krajów ode mnie wyprawionym, Teodorowi i Franciszkowi Lubomirskim, w Jazdowie, D. 28 Novembris A. 1699 [Instructions for My Sons, Teodor and Franciszek Lubomirski, Whom I Sent Abroad, in Jazdów, D. 28 Novembris A. 1699]. In IDEM. Wybór pism [Selected Writings]. Roman Pollak (ed.). Wrocław: Ossolineum, DeAgostini, 2004, p. 291-296. The Instructions were discussed by Zbigniew Chaniecki with special attention paid to the music education of young Lubomirscy. See: CHANIECKI, Zbigniew. Muzyka w Europie w relacjach polskich podróżników [Music in Europe as Accounted by Polish Travellers], Warsaw: Wydawnictwo Naukowe Semper, 2005, p. 166, 171.

14 MEROPE / DRAMA / Da rappresentarsi per Musica / nel famoso Teatro Tron / di San Cassano / Il Carnevale dell'Anno 1711. / CONSACRATO / A SUA ALTEZZA IL SIG. PRINCIPE / TEODORO / COSTANTINO / LUBOMINSHII [!] / Principe del Sacro Romano Imperio. Conte / di Vischnis, e di Jaroslav, Signor / Sovrano di Lublav, Sipour, e / delle tredici Città di / Sepusia, ec.ec. / [vignette] / IN VENEZIA, MDCCXI. / Presso Marino Rossetti. / In Merceria all'Insegna della Pace. / Con Licenza de' Superiori, e Privilegio., p. 3. Copy consulted: I-Mb, Racc. Dramm. Corniani Algarotti 3056.

15 It is truly amazing how Teodor was able to win Joseph I over, considering the fact that during the previous decade he supported the anti-Habsburg rebel, Rákóczi - SZCZYGIELSKI, op. cit., p. 61. Teodor spent 15 months in Vienna (1710-1711) and as of the middle of 1711 he was thought to be returned home. Taking into account Zeno's dedication, the Prince either spent more time in Austrian capital and moved to Venice from there or he indeed did return to Lesser Poland only to embark on another voyage to the South to be present during the Venice carnival.

16 VENCESLAO / Drama per Musica / DA RAPPRESENTARSI / Nel famosissimo Teatro Grimani / di S. Gio: Grisostomo / Nel Carnovale dell'Anno 1722. / DEDICATO / A SUA ALTEZZA IL SIG. PRINCIPE / TEODORO COSTANTINO / LUBOMINSHII [!] / Principe del Sacro Romano Imperio, / Conte di Vischnis, e di Iarosław; / Signor Sovrano di Lublav, Sipour, / e delle tredici Città di Sepusia ec. ec. ec. / Generale di Campo, Maresciallo Lo- / gotenente di Sua Maestà Imperiale. / IN VENEZIA, MDCCXXII. / Presso Marino Rossetti, in Merceria / all'Insegna della Pace. / CON LICENZA DE' SUPERIORI. Copy consulted: I-Rn, 40.9.G.15.3. 
dedicated to Teodor. The opera was set into music by three then-esteemed composers: Giovanni Porta (Act I), Antonio Pollarolo (Act II and Act III) and Giovanni Maria Cappelli (Act IV and Act V). On this occasion, the original five-act structure was restored as well as most of the numbers from the first performance version of $1703 .{ }^{17}$ Seven new arias were added. The choice of this particular work was by no means a random one: the plot was set in Kraków, the dedicatee's headquarters as Kraków Voivod (Spiski Palace at Rynek Główny, named so after the Starost of Spisz office that was served by members of Lubomirscy family for generations). The first performance probably took place at the beginning of February, a few days later Teodor, together with a group of Austrian dignitaries, was received twice during the sumptuous official banquets and before 21 February the Prince left Venice for Rome. ${ }^{18}$ It would remain the open question if the unexpected interest in the character of St. Casimir Jagiellon evident in the oratorio repertoire of the Eternal City during the Lent of 1722 had something in common with the arrival of this Polish aristocrat. ${ }^{19}$

The next opera dedicated to Teodor was La Mariane, staged in November 1724. The work, in fact, was a new version of dramma per musica Gl'eccessi della gelosia (1721) with libretto by Apostolo Zeno's protégé Domenico Lalli with music by Tomaso Albinoni, now with some arias newly composed by Giovanni Porta. ${ }^{20}$ The librettist's dedication referenced to dedications from both Venceslao and Merope. In the very first sentence, it reveals ${ }^{21}$ that it was Lalli who hide covered himself as N. N. in the Venceslao dedication addressed to Teodor. Thus it is possible that the mentioned seven new arias were also penned by him. It is known from other sources that the librettist in question was looking after the wealthy patrons over the Alps and ca. 1722 he had contacts with the

17 The music was then composed by Carlo Francesco Pollarolo. During the next decades the opera was highly succesful throughout the Apennine Peninsula. Several composers penned new music to the libretto, including Giacomo Antonio Perti (Bologna, 1708), Luc'Antonio Predieri (Foligno, 1713) and Francesco Mancini (Napoli, 1714). Most of the settings were reduced to three-act structure, with many new arias added as replacements to the original arias by Zeno.

18 SELFRIDGE-FIELD, op. cit., p. 364.

19 S. CASIMIRO / Prencipe di Polonia / ORATORIO / Di G.B.F. / Posto in Musica / DAL / SIG. GIOSEPPE AMADORI. / E DEDICATO / All'Illustrissimo Signore Avvocato / GASPARE CAGNETTI. / [vignette] / In Roma MDCCXXII. / Nella Stamperia del de Martiis. / Con Licenza de' Superiori. Copy consulted: I-Rn, R.G.Miscell.53 (int. 13). The librettist concealing himself under the initials G.B.F. was probably Giovanni Battista Forlini. The dedication calls upon the then-known solicitor specializing in secular law and working for numerous cardinals in Rome. Teodor, perhaps, was not enthusiastic about the oratorio thus the work could be dedicated to some other person, or maybe the solicitor in question was connected to the Prince. Conceivably, he came to Rome in order to prepare for the complicated case related to his matrimonial plans (that we will deal with later on). These hypotheses are worth investigating in the future.

20 SELFRIDGE-FIELD, op. cit., p. 374.

21 LA MARIANE / DRAMMA PER MUSICA / DI / DOMENICO LALLI / Da Rappresentarsi nel Teatro di / S. ANGELO / L'Autunno dell' Anno / MDCCXXIV. / DEDICATO / A SUA ALTEZZA IL SIG. PRINCIPE / TEODORO COSTANTINO / LUBOMINSHII [!] / Principe del Sacro Romano Imperio, Con- / te di Vischnis, e di Iarosław; Signor / Sovrano di Lublav, Sipour, e delle tre- / dici Città di Sepusia ec. ec. ec. / Generale di Campo, Maresciallo Logote- / nente di Sua Maestà Imperiale. / [vignette] / IN VENEZIA, / Apresso Marino Rossetti, in Merzeria [!] / all'Insegna della Pace. / Con Licenza de' Superiori., p. 3. Copy consulted: I-Vgc, ROLANDI ROL.0132.04. 
Bavarian court as well as the court of the archbishop of Würzburg. ${ }^{22}$ Lalli's interest in Teodor Lubomirski is thus quite natural, as in Venice the Prince was perceived as both fabulously rich aristocrat from the remote country and as a man closely connected with Habsburg house.

The years 1725-1727 mark a new phase in Teodor's relation with Venetian dramma per musica. The Prince staged four operas in his properties in Poland, most probably the main venue was the Spiski Palace in Kraków. The titles included: Venceslao, La fede ne' tradimenti (both staged in 1725), La Mariane (1726) and La Griselda (1727). The Kraków prints of the libretti are known today, all with dedications signed by musicians of His Highness ('li Musici di V. Altezza'), but no music sources that could be connected with Lubomirski's court were discovered so far. The libretti printed in Kraków for the first three operas (Venceslao ${ }^{23}$ La fede ne' tradimenti ${ }^{24}$ and La Mariane ${ }^{25}$ ) strictly follow, to such details as the text layout, the prints that documented Venetian performances. In case of Venceslao and La Mariane the libretti were of course dedicated to Teodor in Venice. It is believed, then, that the operas on Teodore's court were performed with the same music as in Venice. La fede ne' tradimenti, the old libretto by Girolamo Gigli ${ }^{26}$ made references to the highly altered chamber version of the text (for four characters only), that was staged at Teatro S. Angelo in Autumn of 1721 with the music by Carlo Luigi Pietragrua, ${ }^{27}$ thus not long before Teodor's visit to Venice in 1722.

22 STROHM, Reinhard. The Neapolitans in Venice. In Con Che Soavità: Studies in Italian Opera, Song, and Dance, 1580-1740. Iain Fenlon, Tim Carter (eds.). Oxford: Clarendon Press, 1995, p. 255-256.

23 VENCESLAO / Drama per Musica / Da recitarsi per ordine di SUA / ALTEZZA / Il Signor Prencipe / THEODORO CONSTANTINO / LUBOMIRSKI / Prencipe del Sacro Romano Imperio, / Conte di Wisnicz, e di Iarosław; Sta- / rosta d'el[!] Scepusio \&c. Generale di / Campo, Maresciallo Luogotenente di / Sua Maestà Imperiale. / [vignette] / IN CRACOVIA, MDCCXXV. / Presso Giacomo Matyeszkievvicz. / CON LICENZA DE' SUPERIORI. Copy consulted: PL-Kj 26015 I Mag. St. Dr.

24 LA FEDE / NE' TRADIMENTI / DRAMA PER MVSICA / Da recitarsi per ordine di sua / ALTEZZA / $I l$ Signor Prencipe / THEODORO / CONSTANTINO / LUBOMIRSKI / Prencipe del Sacro Romano / Imperio, Conte di Wisnicz, e / di Iarosław; Starosta d'el[!] / Scepusio \&c. Generale / di Campo, Maresciallo Logotenente di sua / Maestà Imperiale. / [vignette] / IN CRACOVIA MDCCXXV. / Presso Giacomo Matyeszkiewicz. / Con Licenza de' Superiori. Copy consulted: RUS-SPsc 6.19.7.63. I thank prof. Alina Żórawska-Witkowska and prof. Barbara Przybyszewska Jarmińska for supplying me with a copy of this libretto.

25 LA MARIANE / DRAMMA PER MVSICA / Da recitarsi per ordine di sua / ALTEZZA / Il Signor Principe / THEODORO / CONSTANTINO / LVBOMIRSKI / Principe del Sacro Romano / Imperio. Conte di Wisnicz, \& / Iarosław, Starosta d'el[!] / Scepu- / sio \&c, Generale di Campo, / Maresciallo Logotenente / di sua Maestà Imperiale. / [vignette] / IN CRACOVIA MDCCXXVI. / Presso Giacomo Matyaszkiewicz. / Con Licenza de Superiori. Copy consulted: PL-ŁA, SD.614. I thank dr. Jana Spáčilová for supplying me with a copy of this libretto.

26 The first performance of the work took place in Siena in Collegio de' Tolomei (1689) with the music by Giuseppe Fabbrini.

27 LA FEDE / NE' TRADIMENTI / DRAMA PER MVSICA / Da recitarsi nel Teatro di S. ANGELO / L'Autunno dell'Anno 1721. / DEDICATO / A' Sua Eccellenza La Signora D. / AVRORA / SANSEVERINO / PRENCIPESSA DELLA / FAMIGLIA GAETANA / DVCHESSA DI / LAVRENZANO. / [vignette] / IN VENEZIA, MDCCXXI. / Presso Marino Rossetti in Merzeria / all'Insegna della Pace. / Con Licenza de' Superiori. Copy consulted: I-Rig, Rar. Libr. Ven. 549/554\#552. 
The fourth libretto, Apostolo Zeno's La Griselda, ${ }^{28}$ poses a complex problem. According to the remark in print, the work was, in fact, a pasticcio ("musica di diversi autori") that was most probably prepared in Kraków. Taking into account the changes of some character's names and the presence of eight specific numbers that were not present in original libretto of 1701 by Zeno (music by Antonio Pollarolo), the Kraków version had to be based on the particular variant of the opera that was staged at Venetian Teatro S. Samuele in 1720 with music by Giuseppe Maria Orlandini. ${ }^{29}$ In this version, Gualtiero is the ruler of Thessaly, his daughter with Griselda, Costanza, was renamed as Oronta and her lover Roberto now appears as Tigrane. In Kraków version, however, the opera had five acts instead of original three, perhaps following the example of French tragedy (the five-act structure of dramma per musica could appear to Teodor as more suitable for court theatre). Moreover, in the Kraków version several scenes were omitted, and Corrado's part cut out. It is thus conceivable that for the Kraków performance the recitatives were taken from Venetian score by Orlandini with as many new numbers added as possible. ${ }^{30}$ The preliminary research of the library holdings that was dealing with the identification of the possible sources of the added musical numbers (at this moment by text incipits) brought no fruit so far. The Kraków libretto was beyond any doubt known in Prague, where it could be brought by the members of Lubomirski's troupe (see below). The pasticcio version of Griselda that was sung in Prague's theatre of Count Sporck in 1731 contains some characteristic features that were introduced earlier in the Kraków print of the libretto (see the table for comparison). ${ }^{31}$

One of the ways to determine the origins of the musical numbers in a pasticcio are careers of the singers involved in a performance, as they used to travel with their favourite arias. However, in case of Lubomirski's ensemble, the names reveal very little despite the fact the troupe consisted of Italians only. The singers contracted for the tournée to a remote country had to be very young ones, and the initial research revealed that only two of them had previous experience on Venetian stages: alto castrato Bartolomeo Straparappa (also spelt as Straparapa or Strapparappa) and Cecilia Grepaldi (Gripaldi). The above does not imply that the artistic level of the troupe was low, on the contrary,

28 LA GRISELDA / DRAMA PER MVSICA / Da recitarsi per ordine di sua / ALTEZZA/ Il Signor Principe / THEODORO / CONSTANTINO / LVBOMIRSKI / Principe del Sacro Roma- / no Imperio, Conte di Wi- / snicz, e Iarosław; Starosta / del Scepusio \&. \&c. Gene- / rale di Campo, Maresci- / allo Logotenente di sua / Maesta Imperiale. / [winieta] / IN CRACOVIA MDCCXXVII. / Presso Giacomo Matyeskzawicz.[!] / Con Licenza de Superiori. Copy consulted: RUS-SPsc 6.17.9.299. I thank prof. Alina Żórawska-Witkowska and prof. Barbara Przybyszewska Jarmińska for supplying me with a copy of this libretto.

29 GRISELDA / Drama per Musica / DA RAPPRESENTARSI / Nel Teatro Grimani di / S. Samuele / Nel Mese di Maggio dell' Anno 1720. / DEDICATO/ All' Illustriss. Sig. il Sig. / GIORGIO PARKER / Figlio unico di Sua Eccellenza / MILORD PARKER / Gran Cancelliere della gran [!] Bretagna. / [winieta] / IN VENEZIA, MDCCXX. / Presso Marin Rossetti all'Insegna / della Pace. / Con Licenza de' Superiori. Copy consulted: I-Bc, Lo.3580.

30 NIUBÒ, Marc. Griselda aneb Triumf ctnosti na opernim jevišti hraběte F. A. Sporcka [Griselda or the Triumph of Virtue on the Opera Stage of Count F. A. Sporck]. In Manu propria... Sbornik př́spěvků k životnímu jubileu Ph Dr. Aleny Richterové. Zuzana Adamaitis, Tereza Paličková (eds.), Praha: Národní knihovna České republiky, 2012, p. 159.

31 In preparation of the comparison table the following table was also helpful: Ibid., p. 171-173. 
most of the singers achieved a considerable position in the world of Italian opera after returning to home country. Straparappa sang in a court chapel of another Polish aristocrat Stanisław Mateusz Rzewuski and later on appeared on a Bavarian court in Munich. Grepaldi performed in Verona, Brescia, Padua, Iesi and Venice. Veneranda Bernina (married Pendesich) appeared on the stages of Venice using the title 'virtuosa del Principe Lubomirski' ${ }^{32}$ and subsequently on the stages of Padua and Prague. Cecilia Delfini (Dolfini, Delflini, married Ramis) sung in Venice, Prague and Brno. Bass Francesco [Maria] Bianchi performed in Wrocław, Prague and London. The most spectacular career, however, was that of Marc'Antonio Mareschi, who appeared on the stages of Wrocław, Venice, Verona, Parma, Padua, Udine and Brno. He performed in the operas by Antonio Vivaldi and from the 1740s to the beginning of 1760s he sang in both seria and buffa repertoire. ${ }^{33}$ The information is sparse only considering Camilla Poli, who was a primadonna of the troupe as it may be judged from the parts she sang (Erenice in Venceslao and title roles in La Mariane and Griselda). After the contract with Lubomirski she sang briefly at the court of Stanisław Mateusz Rzewuski, but after his death in 1728 and dissolution of Hetman's chapel there is no trace of her whereabouts. ${ }^{34}$ The mysterious person remains the soprano castrato Giuseppe (Gioseppe) Giorgio. There are also no clues that could allow us to draw the conclusion that at the court of Teodor was employed some experienced Kapellmeister (maestro di cappella) who could as well compose competently. It should be mentioned, however, that in Respublica in those days the presence of such a person in the chapel was not considered as absolutely necessary, what testifies that the musical interests of many Polish aristocrats were rather superficial and oriented toward external splendor..$^{35}$

The consistent interest of Teodor in the Italian opera lasted only five years in total (1722-1727). It brings out the question why it developed at this particular time and why it lasted for such a short period. It is worth noting, however, that in the realities of the Polish-Lithuanian Commonwealth such ephemeral musical hobbies of aristocrats were by no means uncommon. ${ }^{36}$ It seems that the answer may be hidden in the biography of the Prince. Despite the official pardon for the high treason during the Great Northern

32 SELFRIDGE-FIELD, op. cit., p. 427, 429.

33 The information about singers are given here after www.opac.sbn.it and the following writings: SPÁČILOVÁ, Jana. Soloists of the Opera Productions in Brno, Holešov, Kroměříž and Vyškov. Italian Opera Singers in Moravian Sources c. 1720-1740. In Musicians Mobilities and Music Migrations in Early Modern Europe. Gesa zur Nieden, Berthold Over (eds.). Bielefeld: transkript Verlag, 2016, p. 255-275; KLISOWSKA, Walentyna. Opera włoska we Wrocławiu (1725-1734) i jej związki z innymi ośrodkami muzycznymi [Italian Opera in Wrocław (1725-1734) and Its Relationship With Other Centres]. Italica Wratislaviensia, 2014, no. 5, p. 123-146.

34 I am indebted to dr. Hab. Irena Bieńkowska for the information about the Lubomirski singers who served in the chapel of Stanisław Mateusz Rzewuski.

35 ŻÓRAWSKA-WITKOWSKA, Alina. Muzyka na dworze Jana Klemensa Branickiego [Music at the Court of Jan Klemens Branicki]. In Dwory magnackie w XVIII wieku. Rola i znaczenie kulturowe [Aristocratic Courts in 18th c. Their Role and Cultural Importance]. Teresa Kostkiewiczowa, Agata Roćko (eds.). Warsaw: DiG, 2005, p. 244.

36 For example, the interest in music of the another aristocrat Paweł Karol Sanguszko was short-lived too, as his chapel flourished just between 1729 and 1733. See BIEŃKOWSKA, Irena. Śpiewacy Pawła Karola Sanguszki (1680-1750) w drugiej i trzeciej dekadzie XVIII wieku [Singers of Pawel Karol Sanguszko (1680-1750) in the Second and Third Decade of the 18th c.]. Polski Rocznik Muzykologiczny, 2015, p. 125-137. 
War, Teodor clearly recognized that it would be the best solution not to stick out as an active politician (for the plunders and rapes committed by soldiers in Spiš and Lesser Poland that young Lubomirski consented to and even took part in, he was nicknamed by his subjects as 'the Prince of Infernal Darkness'). ${ }^{37}$ In addition, he created a scandal in 1721, when he had fallen in love with a bourgeois woman Elisabeth Anne Culler-Cumming (a wife of a Kraków merchant), whom he abducted to his estate. Their daughter Anna was born in 1722. In 1724 Teodor married his mistress and in May that year their second child was born, a son Kacper. All that resulted in the couple being ostracised. It is thus possible that Italian journeys of the Prince (we have no information if he was travelling in company of his mistress and - later - his wife; the children were of no consideration as it was common in those times that their upbringing was entrusted to wet nurses) were a form of escapism from the situation in Poland and a way to seek plaudits in some circles that were less well up on Prince's personal affairs and at the same time influenced by the Habsburgs who were favourably inclined towards Lubomirscy (the same reasons could have brought Teodor to Venice earlier at the turn of 1712). Acting as a patron of opera in Poland, with spectacular results, was possibly a part of a well-thought-out policy aimed at standing out against the other aristocrats and even the King's Court of August II, as well as bringing entertainments to himself and his wife that were limited due to ostracism. Moreover, it was an attempt to break the society's aversion by means of sending invitations to attractions that were both expensive and hardly accessible in Poland at the time. The repertoire of Teodor's court theatre was in perfect accord with such aims. The plot of Venceslao, a king's opera (opera regia), reflected the ambitions of an average Polish aristocrat. Every aristocrat dreamt of the crown and to achieve that goal was able to perpetrate any wicked deans against country's best interest only to prevent the other aristocrat, his equal, his 'brother', to be crowned. La fede ne' tradimenti, La Mariane and Griseld $a$ were, in turn, the operas plotted around unusual women who were saving their beloved ones and the country, who were resisting the accusations and inclinations of tyrants. The most characteristic work in this context is the dramma per musica Griselda that tells the story of particular interest to Teodor: the morganatic marriage of Gualtiero with a woman of extraordinary nature and the problems that this brought to the children of the couple. First, it was the daughter and then the son as well, as descendants of the unworthy mother, that were not accepted by subjects as future rulers and heirs to the throne. Gualtiero then put his wife through horrific trials of obedience and fidelity to prove to the subjects that her virtues surpass her modest background and make her worthy spouse of a king. This message, allegorically enhancing the status of Teodor's own wife and children, would be clear to all and any of the guests who would have accepted the invitation from the Prince and to anyone who would come across the print of Griselda libretto. Even to those who knew no Italian, the title itself was a meaningful one, as the history of this righteous and steadfast woman was well-known to Polish nobility. During the 17th and 18th c. in Poland, a dozen or so editions of translations and

37 SZCZYGIELSKI, op. cit., p. 61. 
parodies of this most popular short story from Boccaccio's Decameron were printed..$^{38}$

The direct reason for the end of so fruitfully developing patronage of Teodor was most probably the mourning period at the court. In 1727, as evident from the published genethliacon, the third child of the Prince and Elisabeth was born, a son Józef. ${ }^{39} \mathrm{He}$ is not even mentioned in Polish Biographical Dictionary, so it is highly probable that the child died soon after his birth. It seems as well that with the years the social status of the couple stabilised. At least some of the aristocrats could appreciate the positive influence of Elisabeth upon her husband. Teodor became a more religious person, generous to various church foundations, open to problems of education reform in Poland. Unfortunately for the country the Prince's political ambitions, suppressed for many years, arose. He was conscious of the fact that thirty years reign of August II was about to end and that it was time to prepare for the next royal election. And these ambitions spelt huge expenses. Obviously, Teodor, like many other Polish aristocrats, saw opera as a good way to improve own social status, but contrary to the situation at West-European royal and princely courts, he did not perceive the genre as the medium of political propaganda that would be worth money.

Despite the fact that operas were no more staged in the Prince's residences, the music was probably still present at his court. A small instrumental ensemble was still active there, as evident from the request of Teodor's widow who after his death in 1747 asked another great Polish aristocrat Jan Klemens Branicki to kindly accept to his service a certain Mr. Pio, a violinist, who served for many years in the chapel of Lubomirski. Elisabeth quoted her late husband's opinion who was always very satisfied with Pio's services $^{40}$. The future research, hopefully, will shed new light upon the activity of Teodor's chapel during opera period as well as during the ultimate 15 years of his life.

Transl. Krzysztof Komarnicki

38 ŻABOKLICKI, Krzysztof. La diffusione in Polonia della storia di Griselda. In La storia di Griselda in Europa, Raffaele Morabito (ed.). L'Aquila: Japadre Editore, 1990, p. 225-239; FRANCZAK, Grzegorz. Vix imitabilis: la Griselda Polacca fra letteratura e cultura popolare. Udine - Kraków: Stowarzyszenie Twórcze Artystyczno-Literackie, 2006.

39 Josephus Solatiorum Patriæ Augmentum, Theodorus Munus Cælorum præstantissimum, Ignatius Luminum Congeries, Celsissimvs Purpuratorum Parentum [...] D. Theodori, Comitis in Wisnicz \& Jarosław Lubomirski [...], nec non [...] D. Elisabethæ Annæ Lubomirska Neonatvs, Cæsarum, Ducum, Principum, Senatorum Lectissimus Sangvis, Officioso Apollinis Lvbomirsciani Cultu, Collegij Podolinensis Scholarum Piarum in Fascijs Adoratvs, Anno a Nato universorum Solatio 1727.

40 AGAD, Archiwum Roskie XII-20 [Roś Archive XII-20]: the correspondance of Elisabeth Lubomirska née Cumming, Prince Teodor's wife to Jan Klemens Branicki, letter No. 3 of 25 May 1747, written from Lubomirski residence in Ujazdów, Warsaw. See also: ŻÓRAWSKA-WITKOWSKA, Alina. Muzyka na dworze Jana Klemensa Branickiego. [Music at the Court of Jan Klemens Branicki] In Dwory magnackie w XVIII wieku. Rola $i$ znaczenie kulturowe. [Aristocratic Courts in 18th c. Their Role and Cultural Importance] Teresa Kostkiewiczowa, Agata Roćko (eds.). Warsaw: DiG, 2005, p. 221-244. 
Structures of Griselda libretti in comparison:

\begin{tabular}{|c|c|c|}
\hline Venezia 1720 & Kraków 1727 & Praha 1731 \\
\hline \multicolumn{3}{|c|}{$\begin{array}{l}* \text { - numbers from Zeno's original Griselda staged in Venice in } 1701 \\
* * \text { - numbers from Orlandini's Griselda staged in Venice in } 1720\end{array}$} \\
\hline I/1 Questo, o Popoli, e il giorno... & $\begin{array}{l}\text { I/1 Questo, o Popolo, e il gior- } \\
\text { no... }\end{array}$ & I/1 Questo, o Popolo, e il giorno... \\
\hline $\begin{array}{l}\text { I/2 Eccoti, o Sire, innanzi... } \\
\text { Fa di me ciò che ti piace (Gris.)* }\end{array}$ & $\begin{array}{l}\text { I/2 Eccoti, o Sire, innanzi... } \\
\text { Fa di me ciò che ti piace (Gris.)* }\end{array}$ & I/2 Eccoti, o Sire, innanzi... \\
\hline $\begin{array}{l}\text { I/3 Presto, Signore... } \\
\text { Più non sei no no mia sposa } \\
\text { (Gualt.) }^{* *}\end{array}$ & $\begin{array}{l}\text { I/3 Presto, Signore... } \\
\text { Moglie più non mi sei (Gualt.) } * *\end{array}$ & $\begin{array}{l}\text { I/3 Presto, Signore... } \\
\text { Piu nobile oggetto (Gualt.) }\end{array}$ \\
\hline I/4 Ecco il tempo... & I/4 Ecco il tempo... & I/4 Ecco il tempo... \\
\hline $\begin{array}{l}\text { l/5 Regina se più badi... } \\
\text { Non è la colpa del cor (Gris.) }\end{array}$ & $\begin{array}{l}\text { I/5 Regina se più badi... } \\
\text { La novicella al porto in braccio } \\
\text { (Gris.) }\end{array}$ & $\begin{array}{l}\text { I/5 Regina se più badi... } \\
\text { Senza Regno e si depressa (Gris.) }\end{array}$ \\
\hline $\begin{array}{l}\text { I/6 Troppo avezza è Griselda... } \\
\text { La crudel se par sdegnosa } \\
\text { (Ott.) }{ }^{* * *}\end{array}$ & $\begin{array}{l}\text { I/6 Troppo avezza è Griselda... } \\
\text { La crudel se par sdegnosa } \\
\text { (Ott.) }{ }^{* *}\end{array}$ & $\begin{array}{l}\text { I/6 Troppo avezza è Griselda... } \\
\text { Chi regina mi disprezza (Ott.)* }\end{array}$ \\
\hline I/7 Prenci e Germani... & - & - \\
\hline $\begin{array}{l}\text { I/8 Oronta, eccoti in porto... } \\
\text { Sarai di questo seno (Or. + Tigr.) }\end{array}$ & $\begin{array}{l}\text { II/1 Oronta, eccoti in porto... } \\
\text { Mi fan guerra dentro il core } \\
\text { (Or.) }\end{array}$ & - \\
\hline $\begin{array}{l}\text { I/9 L'arcano in te racchiudi... } \\
\text { Vago sei, volto amoroso } \\
\text { (Gualt.+Cost.)* }\end{array}$ & $\begin{array}{l}\text { II/2 Bella Oronta... } \\
\text { Vago sei, volto amoroso } \\
\text { (Gualt.+Or.)* }\end{array}$ & $\begin{array}{l}\text { I/6 Bellissima Costanza } \\
\text { Vago sei, volto amoroso } \\
\text { (Gualt.+Cost.)* }\end{array}$ \\
\hline $\begin{array}{l}\text { I/10 Se tormi si dovea... } \\
\text { Forse ancora, i bei Trofei (Cor.) }\end{array}$ & - & - \\
\hline $\begin{array}{l}\text { I/11 Quai lusinghe? Si chiara... } \\
\text { Così dubbia Tortorella (Tigr.) }\end{array}$ & $\begin{array}{l}\text { II/3 Al reggio sguardo ahi } \\
\text { troppo... } \\
\text { Afflitto cor ti sento (Tigr.) }\end{array}$ & $\begin{array}{l}\text { I/7 Al reggio sguardo ahi troppo... } \\
\text { Non cede all'austro irato (Rob.)** }\end{array}$ \\
\hline I/12 Parti. Ecco il Re... & $\begin{array}{l}\text { II/4 Parti. Ecco il Re Griselda... } \\
\text { Lieve e rapido (Elp.) }\end{array}$ & - \\
\hline $\begin{array}{l}\text { I/13 Quanto vago è quel sem- } \\
\text { biante (Gualt.+Gris.)* }\end{array}$ & $\begin{array}{l}\text { II/5 - } \\
\text { Se la mia bella amor (Gualt.) }\end{array}$ & $\begin{array}{l}\text { I/8 Quanto vago è quel sem- } \\
\text { biante (Gual.+Gris.)* } \\
\text { Quel basso vapore (Gualt.) }\end{array}$ \\
\hline $\begin{array}{l}\text { I/14 Qual chiedesti, ecco il fi- } \\
\text { glio... } \\
\text { So che vuoi parlar d'amore } \\
\text { (Gris.)* }\end{array}$ & $\begin{array}{l}\text { Il/6 Qual chiedesti, ecco il fi- } \\
\text { glio... } \\
\text { So che vuoi parlar d'amore } \\
\text { (Gris.)* }\end{array}$ & $\begin{array}{l}\text { I/9 Qual chiedesti, ecco il figlio... } \\
\text { So che vuoi parlar d'amore } \\
\text { (Gris.)* }\end{array}$ \\
\hline $\begin{array}{l}\text { I/15 Non giovan le lusinghe... } \\
\text { - } \\
\text { Farò col mio pensier... (Ott.) }\end{array}$ & $\begin{array}{l}\text { Il/7 Non giovan le lusinghe... } \\
\text { La virginella è simile alla Rosa } \\
\text { (Elp.) } \\
\text { Quercia annosa che orgogliosa } \\
\text { (Ott.) }\end{array}$ & $\begin{array}{l}\text { I/15 Non giovan le lusinghe... } \\
\text { - } \\
\text { Benchè mi sia spietata (Ottone) }\end{array}$ \\
\hline $\begin{array}{l}\text { II/1 Son le regie tue stanze... } \\
\text { Occhio che il Sol rimira (Cor.) }\end{array}$ & $\begin{array}{ll}- \\
- \\
-\end{array}$ & 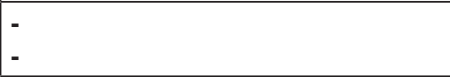 \\
\hline II/2 Pria che d'amar ti lasci... & $\begin{array}{l}\text { Il/8 Pria che d'amar ti lasci... } \\
\text { Vede quel Pastorello (Tigr.) }\end{array}$ & $\begin{array}{l}\text { l/11 Pria che d'amar ti lasci... } \\
\text { Veggo la sponda (Cost.) }\end{array}$ \\
\hline $\begin{array}{l}\text { II/3 Signora, il Re tuo sposo... } \\
\text { Mentre un ape sta scherzando } \\
\text { (Or.) } * *\end{array}$ & $\begin{array}{l}\text { II/9 Signora, il Re tuo sposo... } \\
\text { Mentre un ape sta scherzando } \\
(\text { Or. })^{* *}\end{array}$ & $\begin{array}{ll}- \\
-\end{array}$ \\
\hline
\end{tabular}


Between Venice, Lubowla in Spiš and Kraków: Prince Teodor Lubomirski - An Enthusiast ...

\begin{tabular}{|c|c|c|}
\hline Venezia 1720 & Kraków 1727 & Praha 1731 \\
\hline $\begin{array}{l}\text { II/4 E nel core di Oronta.... } \\
\text { Quella fiamma che mi sface } \\
\text { (Tigr.) }\end{array}$ & $\begin{array}{l}\text { II/10 E nel core di Oronta.... } \\
\text { Va mio core alla mia bella (Tigr.) }\end{array}$ & $\begin{array}{l}\text { I/12 E nel cor di Costanza... } \\
\text { Tortorella cui rapita (Rob.) }\end{array}$ \\
\hline $\begin{array}{l}\text { II/5 Care selve, a voi ritorno } \\
\text { (Gris.)* }\end{array}$ & $\begin{array}{l}\text { III/1 Care selve, a voi ritorno } \\
\text { (Gris.)* }\end{array}$ & $\begin{array}{l}\text { II/1 Care selve, a voi ritorno } \\
\text { (Gris.)* }\end{array}$ \\
\hline II/6 O Griselda, Griselda... & $\begin{array}{l}\text { III/2 O Griselda, Griselda... } \\
\text { Corre veloce il piede (Elp.) } \\
\end{array}$ & ------O Griselda, Griselda... \\
\hline II/7 Ferma, Griselda... & III/3 Ferma, Griselda... & -------Ne tutta ancor sai... \\
\hline $\begin{array}{l}\text { II/8 Fermati, Otton... } \\
\text { Quel volto amabile (Ott.) }\end{array}$ & \begin{tabular}{|l|} 
III/4 Fermati, Otton... \\
Ad amar vaga beltade (Ott.)
\end{tabular} & $\begin{array}{l}\text { II/2 Fermati, Otton... } \\
\text { La bella nemica (Ott.)* }\end{array}$ \\
\hline $\begin{array}{l}\text { II/9 È deliquio di core... } \\
\text { Vieni o sonno a queste luci } \\
\text { (Gris.).** }\end{array}$ & $\begin{array}{l}\text { III/5 È deliquio di core... } \\
\text { Vieni o sonno a queste luci } \\
\text { (Gris.)*** }\end{array}$ & $\begin{array}{l}\text { II/3 È deliquio di core... } \\
\text { Vieni o sonno a queste luci } \\
\text { (Gris.) }^{* *}\end{array}$ \\
\hline $\begin{array}{l}\text { II/10 Sinche'l Re... } \\
\text { Augeletto che levasi a volo (Tig.) }\end{array}$ & \begin{tabular}{|l|} 
III/6 Sinche'l Re... \\
Parto, sì, ma tutto fede (Tig.)
\end{tabular} & $\begin{array}{l}----- \text { Sinche'l Re... } \\
\text { Lascia, s'io parto, almeno (Rob.) }\end{array}$ \\
\hline II/11 Sola, se ben tu parti... & $\begin{array}{l}\text { III/7 Sola, se ben tu parti... } \\
\text { Vago augeletto (Or.) }\end{array}$ & $\begin{array}{l}\text { II/4 Sola, se ben tu parti... } \\
\text { S'io quella fossi, allor (Gris.) }\end{array}$ \\
\hline II/12 De'tuoi be'sguardi... & \begin{tabular}{|l|} 
III/8 De'tuoi be'sguardi... \\
Saresti I'idol mio (Gualt.) \\
\end{tabular} & $\begin{array}{ll}- \\
- \\
\end{array}$ \\
\hline $\begin{array}{l}\text { II/13 Avvisato dal servo... } \\
\text { Vorresti col tuo pianto (Gualt.)* }\end{array}$ & $\begin{array}{ll}- \\
- \\
\end{array}$ & $\begin{array}{ll}- \\
- \\
\end{array}$ \\
\hline II/14 Ecco Oton. Sola... & $\begin{array}{l}\text { III/9 Griselda (O ciel, che veg- } \\
\text { gio!) }\end{array}$ & $\begin{array}{l}\text { II/5 Griselda, ecco il estremo } \\
\text { giorno... }\end{array}$ \\
\hline $\begin{array}{l}\text { II/15 Lo impone il Re? Sei troppo } \\
\text { fido... } \\
\text { - }\end{array}$ & $\begin{array}{l}\text { III/10 Ecco il fellon... } \\
\text { Più contento da suo monte } \\
\text { (Ott.) }\end{array}$ & $\begin{array}{l}\text {----Lo impone il Re? Sei troppo } \\
\text { fido Ottone... }\end{array}$ \\
\hline $\begin{array}{l}\text { II/16 Qual grazie posso?... } \\
\text { A parte del cor mio (Or.)**. }\end{array}$ & $\begin{array}{l}\text { III/11 Qual grazie posso?... } \\
\text { A parte del cor mio (Or.) }{ }^{* * *}\end{array}$ & $\begin{array}{l}\text { II/6 Quai grazie posso?... } \\
\text { Soffre tal ora dal vento (Gualt.) }\end{array}$ \\
\hline $\begin{array}{l}\text { II/17 Serva mi vuol la sorte... } \\
\text { Vedrassi nel suo nido (Gris.) }\end{array}$ & $\begin{array}{l}\text { III/12 Serva mi vuol la sorte... } \\
\text { Al rigor di stella irata (Gris.) }\end{array}$ & $\begin{array}{l}\text { II/7 Serva mi vuol la sorte... } \\
\text { Vieni, ma oh Dio nel petto (Cost. } \\
\text { + Gris.) }\end{array}$ \\
\hline $\begin{array}{l}\text { III/1 Otton qui mi si guidi... } \\
\text { - }\end{array}$ & $\begin{array}{l}\text { IV/1 Otton qui mi si guidi... } \\
\text { Canta per la campagna (Gualt.) }\end{array}$ & $\begin{array}{l}\text { II/8 Otton qui mi si guidi... } \\
\text { - }\end{array}$ \\
\hline $\begin{array}{l}\text { III/2 Amor, prestami aita... } \\
\text { Vermiglia aurora (Ott.) }\end{array}$ & $\begin{array}{l}\text { IV/2 Amor, tu dammi aita... } \\
\text { Gravida nube oscura (Ott.) } \\
\end{array}$ & $\begin{array}{l}\text {-------Amor, dammi tu aita... } \\
\text { Vedi o Re nel mio conteno (Ott.) }\end{array}$ \\
\hline III/3 Da l'amor di costui... & $\begin{array}{l}\text { IV/3 Da l'amor di costui... } \\
\text { Nobil onda che dal monte } \\
\text { (Gual.) }\end{array}$ & $\begin{array}{l}\text { II/9 Dall'amor di costui... } \\
\text { Son qual stanco Pellegrino } \\
\text { (Gual.) }\end{array}$ \\
\hline $\begin{array}{l}\text { III/4 Anche nel mio dolore... } \\
\text { Per me non v'è chi parli (Gris.)*** }\end{array}$ & $\begin{array}{l}\text { IV/4 Anche nel mio dolore... } \\
\text { Per me non v'è chi parli (Gris.)*** }\end{array}$ & $\begin{array}{ll}- \\
-\end{array}$ \\
\hline $\begin{array}{l}\text { III/5 Risoluta è quest'alma... } \\
\text { Quelle pupille si (Cor.) }\end{array}$ & $\begin{array}{l}\text { V/1 Non sia mai ver... } \\
\text { Non puo piu saldarsi (Or.) } \\
\end{array}$ & $\begin{array}{ll}- \\
- \\
\end{array}$ \\
\hline $\begin{array}{l}\text { III/6 Tu partire, o Tigrane... } \\
\text { Quando lungi sentirai (Tig.+Or.) }\end{array}$ & \begin{tabular}{|l|} 
V/2 Tu partire, o Tigrane... \\
Cara partir voglio (Tig.+Or.) \\
\end{tabular} & $\begin{array}{l}\text { III/1 Tu partire, o Roberto... } \\
\text { - }\end{array}$ \\
\hline $\begin{array}{l}\text { III/7 E per sempre vi unisca } \\
\text { amanti fidi... }\end{array}$ & $\begin{array}{l}\text { V/3 E per sempre vi unisca } \\
\text { amanti fidi... }\end{array}$ & $\begin{array}{l}\text {------E per sempre vi unisca } \\
\text { amanti fidi... }\end{array}$ \\
\hline $\begin{array}{l}\text { III/8 Griselda - (II Re)... } \\
\text { Se amori ascolterò (Gris.)* }\end{array}$ & $\begin{array}{l}\text { V/4 Griselda - (II Re)... } \\
\text { Se amori ascolterò (Gris.)* }\end{array}$ & $\begin{array}{l}\text { III/2 Griselda - (II Re)... } \\
\text { Se amori ascolterò (Gris.)* }\end{array}$ \\
\hline
\end{tabular}




\begin{tabular}{|c|c|c|}
\hline Venezia 1720 & Kraków 1727 & Praha 1731 \\
\hline $\begin{array}{l}\text { III/9 Temo. - Pavento... } \\
\text { Non partir da chi ti adora } \\
\text { (Gualt.)* }\end{array}$ & $\begin{array}{l}\text { V/5 Temo. - Pavento... } \\
\text { Non partir da chi ti adora } \\
\text { (Gualt.)* }\end{array}$ & $\begin{array}{l}\text { III/3 Temo. - Pavento... } \\
\text { Foco ugual il sen v'accenda } \\
\text { (Gualt.) }\end{array}$ \\
\hline $\begin{array}{l}\text { III/10 (Non m'inganno?)... } \\
\text { Begli occhi io ben vorrei (Tigr.) }{ }^{* *}\end{array}$ & 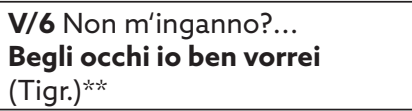 & $\begin{array}{l}\text { III/4 (Non m'inganno?)... } \\
\text { Non so, se più mi piaci (Rob.) }\end{array}$ \\
\hline $\begin{array}{l}\text { III/11 D'una fede si bella... } \\
\text { Fra tempeste (Or.) }\end{array}$ & $\begin{array}{l}\text { V/7 D'una fede si bella... } \\
\text { Fra due venti Navicella (Or.) }\end{array}$ & $\begin{array}{l}\text { III/5 D'una fede si bella... } \\
\text { Ardi per me fedele (Cost.) }\end{array}$ \\
\hline- & $\begin{array}{l}\text { V/8 Che rechi Elpin. } \\
\text { Augelin, ch'al piano scende } \\
\text { (Elp.) }\end{array}$ & III/6 O quante stravaganze... \\
\hline- & $\begin{array}{l}\text { V/9 O Ciel ch'udii... } \\
\text { Vo lusingarmi (Ott.) }\end{array}$ & - \\
\hline III/12 Ministri, accelerate... & V/10 Ministri, accelerate... & III/7 Ministri, accelerate... \\
\hline $\begin{array}{l}\text { III/13 Griselda - Altro non man- } \\
\text { ca... } \\
\text { - } \\
\text { Dopo l'orribile, fiero timor } \\
\text { (coro) } * * 41\end{array}$ & $\begin{array}{l}\text { V/11 Griselda - Altro non man- } \\
\text { ca... } \\
\text { Quale e quanta mi scende nel } \\
\text { petto (Or.) } \\
\text { Dopo l'orribile, fiero timor } \\
\text { (coro) }{ }^{* *}\end{array}$ & $\begin{array}{l}\text {--- Griselda - Altro non manca... } \\
\text { Dopo l'orribile, fiero timor } \\
\text { (coro) } * \text {. }\end{array}$ \\
\hline
\end{tabular}

\section{Bibliography}

BIEŃKOWSKA, Irena. Śpiewacy Pawła Karola Sanguszki (1680-1750) w drugiej i trzeciej dekadzie XVIII wieku. Polski Rocznik Muzykologiczny, 2015, p. 125-137.

CHANIECKI, Zbigniew. W sprawie kapeli Stanisława Lubomirskiego i początków opery włoskiej w Polsce. Muzyka, 1968, vol. 13, no. 3, p. 58-65.

CHANIECKI, Zbigniew. Muzyka w Europie w relacjach polskich podróżników, Warsaw: Wydawnictwo Naukowe Semper, 2005.

FORLINI. Giovanni Battista [? G.B.F.]. S. Casimiro Prencipe di Polonia. Oratorio di G.B.F. posto in musica dal Sig. Gioseppe Amadori e dedicato all'Illustrissimo Signore Avvocato Gaspare Cagnetti. Roma: de Martiis, 1722.

FRANCZAK, Grzegorz. Vix imitabilis: la Griselda Polacca fra letteratura e cultura popolare. Udine Kraków: Stowarzyszenie Twórcze Artystyczno-Literackie, 2006.

GIGLI, Girolamo. La fede ne' tradimenti. Drama per musica da recitarsi nel Teatro di S. Angelo l'Autunno dell' Anno 1721. Dedicato A' Sua Eccellenza La Signora D. Aurora Sanseverino [...].Venezia: Marino Rossetti, 1721.

GIGLI, Girolamo. La fede ne' tradimenti. Drama per musica da recitarsi per ordine di sua Altezza Il Signor Prencipe Theodoro Constantino Lubomirski [...]. Cracovia: Giacomo Matyeszkiewicz, 1725.

Josephus Solatiorum Patrice Augmentum, Theodorus Munus Calorum prestantissimum, Ignatius Luminum Congeries, Celsissimvs Purpuratorum Parentum [...] D. Theodori, Comitis in Wisnicz E Jarostaw Lubomirski [...], nec non [...] D. Elisabetha Anna Lubomirska Neonatvs, Cesarum, Ducum, Principum, Senatorum Lectissimus Sangvis, Officioso Apollinis Lvbomirsciani Cultu, Collegij Podolinensis Scholarum Piarum in Fascijs Adoratus, Anno a Nato universorum Solatio 1727.

41 Final Coro taken from Zeno's Merope. 
KERSTEN, Adam. [entry] Lubomirski Jerzy Sebastian h. Szreniawa. In Polski Stownik Biograficzny. Emanuel Rostworowski (ed.). Wrocław - Warszawa - Kraków: Zakład Narodowy im. Ossolińskich - Wydawnictwo Polskiej Akademii Nauk, 1973, vol. 18, p. 14-20.

KLISOWSKA, Walentyna. Opera włoska we Wrocławiu (1725-1734) i jej związki z innymi ośrodkami muzycznymi. Italica Wratislaviensia, 2014, no. 5, p. 123-146.

KUNICKI-GOLDFINGER, Marek. Listy Stanisława Herakliusza Lubomirskiego. In Stanistaw Herakliusz Lubomirski - twórca i dzieta. Adam Karpiński - Estera Lasocka (eds.). Warsaw: Instytut Badań Literackich, 2004, p. 33-57.

LALLI, Domenico. La Mariane. Dramma per musica di Domenico Lalli da rappresentarsi nel Teatro di S. Angelo l'Autunno dell' Anno MDCCXXIV. Dedicato a sua altezza il Sig. Principe Teodoro Costantino Lubominshii [...]. Venezia: Marino Rossetti, 1724.

LALLI, Domenico. La Mariane. Dramma per musica da recitarsi per ordine di sua Altezza il Signor Principe Theodoro Constantino Lubomirski [...]. Kraków: Giacomo Matyaszkiewicz, 1726.

LUBOMIRSKI, Stanisław Herakliusz. Instrukcyja synom moim [do] cudzych krajów ode mnie wyprawionym, Teodorowi i Franciszkowi Lubomirskim, w Jazdowie, D. 28 Novembris A. 1699. In IDEM. Wybór pism. Roman Pollak (ed.). Wrocław: Ossolineum, DeAgostini, 2004, p. 291-296.

NIUBÒ, Marc. Griselda aneb Triumf ctnosti na opernim jevišti hraběte F. A. Sporcka [Griselda or the Triumph of Virtue on the Opera Stage of Count F. A. Sporck]. In Manu propria... Sbornik př́spěvkư k životnimu jubileu PhDr. Aleny Richterové. Zuzana Adamaitis, Tereza Paličková (eds.), Praha: Národní knihovna České republiky, 2012, p. 155-174.

PRZYBOŚ, Adam. [entry] Lubomirski Józef Karol h. Szreniawa. In Polski Stownik Biograficzny. Emanuel Rostworowski (ed.). Wrocław - Warszawa - Kraków: Zakład Narodowy im. Ossolińskich - Wydawnictwo Polskiej Akademii Nauk, 1973, vol. 18, p. 26-27.

SELFRIDGE-FIELD, Eleanor. A New Chronology of Venetian Opera and Related Genres, 1660-1760. Stanford: Stanford University Press, 2007.

SPÁČILOVÁ, Jana. Soloists of the Opera Productions in Brno, Holešov, Kroměříž and Vyškov. Italian Opera Singers in Moravian Sources c. 1720-1740. In Musicians Mobilities and Music Migrations in Early Modern Europe. Gesa zur Nieden, Berthold Over (eds.). Bielefeld: transkript Verlag, 2016, p. 255-275.

STROHM, Reinhard. The Neapolitans in Venice. In Con Che Soavità: Studies in Italian Opera, Song, and Dance, 1580-1740. Iain Fenlon, Tim Carter (eds.). Oxford: Clarendon Press, 1995, p. 249-274.

SZCZYGIELSKI, Wacław. [entry] Lubomirski Teodor h. Szreniawa. In Polski Stownik Biograficzny. Emanuel Rostworowski (ed.). Wrocław - Warszawa - Kraków: Zakład Narodowy im. Ossolińskich - Wydawnictwo Polskiej Akademii Nauk, 1973, vol. 18, p. 60-63.

WIMMER, Jan. [entry] Lubomirski Hieronim Augustyn h. Szreniawa. In Polski Stownik Biograficzny. Emanuel Rostworowski (ed.). Wrocław - Warszawa - Kraków: Zakład Narodowy im. Ossolińskich - Wydawnictwo Polskiej Akademii Nauk, 1973, vol. 18, p. 11-14.

ZENO, Apostolo. La Griselda. Drama per musica da rappresentarsi nel Teatro Grimani di S. Samuele nel Mese di Maggio dell' Anno 1720. Dedicato all' Illustriss. Sig. il Sig. Giorgio Parker [...].Venezia: Marino Rossetti, 1720.

ZENO, Apostolo. Griselda. Drama per musica da recitarsi per ordine di sua Altezza Il Signor Principe Theodoro Constantino Lubomirski [...]. Cracovia: Giacomo Matyeskzawicz[!], 1727.

ZENO, Apostolo. Merope. Drama da rappresentarsi per musica nel famoso Teatro Tron di San Cassano il Carnevale dell'Anno 1711. Consacrato a sua altezza il Sig. Principe Teodoro Costantino Lubominshii [...]. Venezia: Marino Rossetti, 1711. 
ZENO, Apostolo. La Mariane. Dramma per musica da recitarsi per ordine di sua Altezza Il Signor Principe Theodoro Constantino Lubomirski [...]. Cracovia, Giacomo Matyaszkiewicz, 1726.

ZENO, Apostolo. Venceslao. Drama per Musica da rappresentarsi nel famosissimo Teatro Grimani di S. Gio: Grisostomo nel Carnovale dell' Anno 1722. Dedicato a sua altezza il Sig. Principe Teodoro Costantino Lubominshii. Venezia: Marino Rossetti, 1722.

ZENO, Apostolo. Venceslao. Drama per Musica da recitarsi per ordine di Sua Altezza Il Signor Prencipe Theodoro Constantino Lubomirski [...]. Cracovia: Giacomo Matyeszkievvicz, 1725.

ZIELIŃSKA, Teresa. Poczet polskich rodów arystokratycznych. Warsaw: Wydawnictwa Szkolne i Pedagogiczne, 1997.

ŻABOKLICKI, Krzysztof. La diffusione in Polonia della storia di Griselda. In La storia di Griselda in Europa, Raffaele Morabito (ed.). L'Aquila: Japadre Editore, 1990, p. 225-239.

ŻÓRAWSKA-WITKOWSKA, Alina. Muzyka na dworze Jana Klemensa Branickieg. In Dwory magnackie w XVIII wieku. Rola i znaczenie kulturowe. Teresa Kostkiewiczowa, Agata Roćko (eds.). Warsaw: DiG, 2005, p. 221-244. 
